\title{
Building Peace over Water in South Asia: The Watercourses Convention and SAARC
}

\author{
By Ravindra Pratap*
}

South Asia is one of the most water-stressed regions in the world and home to the Earth's largest number of poor. Water problems of South Asia come from a welter of complex sources. The lack of a desirable normative framework for transboundary water sharing adds to the problem of water sharing for the existence in South Asia of the two declared nuclear weapon states of India and Pakistan as water remains one of the key unresolved problems between these two South Asian countries. Although the South Asian region is not without water sharing arrangements, including treaties, we do not really have principles of water sharing. The paper therefore suggests that the South Asian country members of the South Asian Association for Regional Cooperation (SAARC) become parties to the 1997 Watercourses Convention with any appropriate reservations and/or declarations and establish a SAARC cooperation mechanism for a necessary effectuation and institutional monitoring of equity, reasonableness, flexibility and adaptation in the South Asian water sharing.

Keywords: Water, South Asia, Watercourses Convention, Customary International Law, SAARC.

\section{Introduction}

Water sustains life. ${ }^{1}$ That water is unsubstitutable for human survival is sadly compounded by the fact that the Earth's largest number of poor inhabits in South Asia. Water problems of South Asia come from a welter of complex sources: rising demand for water due mainly to the rising population ${ }^{2}$ and the imperatives of development, ${ }^{3}$ water "mismanagement", ${ }^{4}$ uneven distribution, ${ }^{5}$ environmental flows, ${ }^{6}$ and climate change. Water supply from rains is seasonal and ironically produces both floods and drought. ${ }^{7}$ Thus, there is a fresh water

\footnotetext{
* Associate Professor, Faculty of Legal Studies, South Asian University, New Delhi, India. Email addresses: ravindrapratap@sau.int; ravindrapratap@ hotmail.com. The author is grateful to Dr. Gregory T. Papanikos for a timely opportunity to make this contribution and to Professor David A. Frenkel, LL.D. for his prompt reverts and edits on earlier drafts. The author also wishes to thank the anonymous referees and members of the ATINER staff for their kind facilitation for the 14th Annual International Conference, 10-13 July 2017, Athens, Greece. Only the author is responsible for all errors and infelicities.

${ }^{1}$ Türk (2012).

${ }^{2}$ Kraska (2003) at p. 481; Qureshi (2011) at p. 254.

${ }^{3}$ Further, see Tarlock (2008).

${ }^{4}$ Adhikari (2014).

${ }^{5}$ Kraska (2003), at p. 477.

6 "Whereas the primary water issue in the west is scarcity, in the east it is abundance." Shah and Giordano (2013) at p. 28.

7 "Water flowing in rivers has for present purposes three salient aspects: (a) the hydrologic
} 
crisis $^{8}$ in South Asia which is "among the most water-stressed regions on the planet."

But water can be shared. ${ }^{10}$ Sharing is based on the idea that water does not belong to anyone. While the importance of water sharing has been long felt, the "functional utility of transboundary river agreements" $" 11$ has not been adequately appreciated. If this could be duly appreciated, for instance, India may reasonably store and Bangladesh may reasonably use the Brahmaputra's waters to address salinity. The lack of a desirable normative framework adds to the problem of water sharing which is bound to become "complex as water quality, water efficiency, energy needs, climate change and demographic pressures place increasing demands on already-scarce water resources" 12 While the impact of human activities generally has been considered to be commonly most widespread, ${ }^{13}$ perhaps a more worrying source of the problem is the existence in South Asia of the two declared nuclear weapon states of India and Pakistan ${ }^{14}$ as water remains one of the key unresolved problems between these two South Asian countries. ${ }^{15}$ Although the South Asian region is not without water sharing arrangements, including treaties, we do not really have principles of water sharing. And where we have principles, ${ }^{16}$ we have no adherence. ${ }^{17}$

The paper argues for the observance by the South Asian countries of the customary international law contained in the 1997 Watercourses Convention and for appropriately establishing a regional cooperation mechanism for water sharing in South Asia. Accordingly, the next part briefly recapitulates the principal legal regimes of water sharing in the region. Part III briefly reviews the functioning of the principal regimes of water sharing between the South Asian Association for Regional Cooperation (SAARC) countries. The paper then gives in part IV an overview of the salient features of the Watercourses

cycle, (b) self-purification, and (c) variations in quantity and flow." The Law of the NonnavigationalUses of International Watercourses, First Report (1979) at 146, para. 8; Kumar and Jain (2011) at p. 42.

${ }^{8}$ Wirsingh (2011) at p. 39.

${ }^{9}$ Kraska (2003) at p. 466; The Economist, South Asia's water: unquenchable thirst, November 19, 2011. 14 per cent people in the SAARC region did not have in 2002 access to safe-drinking water. SAARC Development Goals, 2007-2012, para. 24, http://saarc-sec.org/download/publications/ TAKING_SDGs_FORWARD_(saarc-sec_20100616032736.pdf (accessed 12 May 2017).

${ }^{10}$ See generally, UN-Water. (2008); Sadoff et al (2008); Boisson de Chazournes (2009); Wouters and Rieu-Clarke (2004); Benevisti (2002).

${ }^{11}$ Kraska (2003) at p. 467.

${ }^{12}$ Miner et al. (2009) at p. 214.

13 "The negative impact of human activities on the waters of the river may affect other components of the ecosystem of the watercourse such as its flora, fauna, and soil." Case Concerning Pulp Mills on the River Uruguay (Argentina v. Uruguay), para. 188.

${ }^{14}$ Abbas (1984); Gleick (1993); Swain (1996); Gyawali (2002); Salman and Uprety (2002); AyubQutub, S. et al (2003); Swain (2004); Rahaman (2006); Priscoli and Wolf (2009); Biswas (2011); Chellaney (2011).

${ }^{15}$ Dar (2011-2012) at 2.

${ }^{16}$ The 1997 Watercourses Convention, see below, section IV. Further, for a background, see generally, Barber (1981); Zacklin and Caflish (eds.) (1981).

${ }^{17}$ None of the SAARC countries are parties to the Watercourses Convention. 
Convention. And, finally, Part V concludes upon suggesting an outline of the cooperation mechanism.

\section{Overview of the Principal Legal Regimes of Water sharing between the SAARC Countries}

Three such regimes may be identified: India and Pakistan, India and Bangladesh, and India and Nepal. Each of these will be discussed briefly.

\section{India and Pakistan}

India and Pakistan were part of the British India before 1947 and thus only the British India was responsible for laying the foundations of the watersharing regime between India and Pakistan. The regime comprises of and concerns the six rivers of the Indus basin (Indus, Jhelum, Chenab, Sutlej, Beas and Ravi) which originate in the Himalayas and pass through India and the Indian state of Jammu and Kashmir before crossing over to Pakistan and part of Jammu and Kashmir controlled by Pakistan. ${ }^{18}$ India and Pakistan agreed in 1948 to pay as charges for the re-establishment of water flow. But Pakistan repudiated it in 1951, characterizing it as unfair, and the dispute did not resolve until both the countries signed the Indus Waters Treaty (IWT) in $1960 .{ }^{19}$

The IWT was signed to regulate water sharing between the two countries after "the Indian government resisted Pakistan's 1949 proposal to take the Indus waters dispute to the Court." ${ }^{, 0}$ While the three western rivers (Indus, Jhelum and Chenab) were assigned to Pakistan, India "retained the right to use these rivers for the purposes of generation of the hydroelectric power. ${ }^{21}$ And despite otherwise strained relations between India and Pakistan, the IWT has survived all conflicts between them. ${ }^{22}$ The International Law Commission (ILC) has termed the IWT as one of "the prime cases of equitable apportionment or utilization." 23

\section{India and Bangladesh}

Bangladesh is a least-developed country of South Asia which attained independence from Pakistan in 1971. After a number of short-term agreements

\footnotetext{
18 "This led to the internationalization of the water dispute and a negotiation process began to agree over the terms for use of water in the Indus basin." Dar (2011-2012), at 2. Further, see Michel (1967).

${ }^{19}$ Haines (2014) at p. 646: Biswas (1992). For the text of the IWT, visit http://siteresources.worldba nk.org/INTSOUTHASIA/Resources/223497-1105737253588/IndusWatersTreaty1960.pdf.

(accessed 13 April 2017). Further, for a background of the IWT, see also The Indus Waters Kishenganga Arbitration (Pakistan v. India), Partial Award of the Permanent Court of Arbitration, dated 18 February 2013, para. 130 et seq. [hereinafter the "Kishenganga Partial Award"].

${ }^{20}$ Haines (2014) at 640.

${ }^{21}$ Article III (2) of the IWT; Uprety and Salman (2011) at p. 643.

${ }^{22}$ Further, see Gulhati (1973).

${ }^{23}$ The Law of the Non-navigational Uses of International Watercourses, Third Report (1982), 146, para. 65.
} 
signed between Bangladesh and India since 1972 for sharing the Ganges waters at Farakka, India and Bangladesh signed the Ganges Waters Treaty in 1996 for a period of thirty years. ${ }^{24}$ A dispute had emerged between India and Bangladesh as a result of India's construction of the Farakka Barrage on the Ganges in 1975, which had been termed as "the Kashmir of Bangladesh's grievances with India". 25 "

The Treaty aims at sharing the Ganges waters at Farakka, ${ }^{26}$ which further lays down that the waters released to Bangladesh will not be reduced below Farakka except for reasonable uses by India. ${ }^{27}$ The Treaty establishes a joint committee to record the daily flow of waters at Farakka ${ }^{28}$ and to serve as the first mechanism for resolving any difference or dispute between the two countries arising out of implementation of the Treaty. Any such unresolved difference or dispute shall be next referred to the joint-river commission and finally to the governments of the two countries. ${ }^{29}$ The Treaty is guided by equity, fairness and no harm to either party. ${ }^{30}$

\section{India and Nepal}

Nepal is a land-locked country and one of the least-developed countries in South Asia. The instant regime consists of three treaties of 1954, 1959 and 1996.

The 1954 India-Nepal Agreement (revised in 1996) on the Kosi River Project $^{31}$ was for the purposes of flood control, irrigation and generation of hydroelectric power. The Treaty recognizes that the Chief Engineer of the Indian province of Bihar may be authorized by Nepal to conduct investigation and surveys of the Project. The Treaty expressly contemplates the use of water and power by Nepal, royalties, compensation for land, navigation rights, fishing rights, use of Nepali labour, the possibility of arbitration for the settlement of disputes, and of revision in the changed circumstances. ${ }^{32}$

The 1959 Gandak River Treaty between India and Nepal (amended 1964) ${ }^{33}$ also concerns irrigation and power project. The Treaty provides for protection of Nepal's riparian rights. ${ }^{34}$ The Treaty expressly states India's ownership, operation and maintenance of works, ${ }^{35}$ power generation and reservation for

\footnotetext{
${ }^{24}$ Treaty between the Government of the People's Republic of Bangladesh and the Government of the Republic of India on the Sharing of the Ganga/Ganges Waters at Farakka, 1996, Article XII. For the text of Treaty, visit http://www.jrcb.gov.bd/attachment/Gganges_Water_Sharing_treaty, 1996.pdf (accessed 29 April 2017).

${ }^{25}$ Haider (2001) at p. 425; Islam (1984); Abbas (1983).

${ }^{26}$ Article I of the Treaty.

${ }^{27}$ Article III of the Treaty.

${ }^{28}$ Article IV of the Treaty.

${ }^{29}$ Article VII of the Treaty.

${ }^{30}$ Article IX of the Treaty.

31 For the text, visit https://www.internationalrivers.org/sites/default/files/attached-files/treaties_ between_nepal-india.pdf(accessed 05 June 2017).

${ }^{32}$ Preamble to the Treaty.

${ }^{33}$ For the text, visit https://www.internationalrivers.org/sites/default/files/attached-files/treaties between_nepal-india.pdf(accessed 05 June 2017).

${ }^{34}$ Article 9 .

${ }^{35}$ Article 6.
} 
Nepal, non-derogation of Nepal's sovereignty and jurisdiction over the land given by Nepal to India for the purposes of the execution of the project ${ }^{36}$ and provides for arbitration for the settlement of disputes. ${ }^{37}$

The most important here is the 1996 Mahakali Treaty between India and Nepal. ${ }^{38}$ The Mahakali Treaty incorporates the principle of equitable and reasonable utilization inasmuch as the equal utilization is without prejudice to the existing uses of the parties. ${ }^{39}$ The Treaty envisages a Commission that is required in its work to be guided by no harm to either party. ${ }^{40}$ Each Party has undertaken not to use or obstruct or divert the waters of the Mahakali River adversely affecting its natural flow and level except by an agreement between the parties. ${ }^{41}$ Salman and Uprety hope that "the Mahakali will be developed in an integrated way to maximise the total net benefit from development."42 However, the functioning of the Treaty hardly allows a conclusion that it has been able to resolve all matters that arise out of it. Some of these will be the subjects of discussion in the next section.

\section{Functioning of the Principal Legal Regimes of Water sharing between the SAARC Countries}

The functioning of the principal legal regimes of water sharing in South Asia points to a number of shortcomings. Limitations of the existing water sharing regimes in the South Asian region and their potential to degenerate into conflicts are attributable to a host of factors. Water disputes in the region "can be traced back to the institutions created by the British Raj." ${ }^{\text {"3 }}$ The very nature of transboundary movement of water and its common economic importance to the states make water sharing "a forum for relinquishing or asserting exclusive sovereignty" 44 and thus potentially "a fulcrum for peace or war" in South Asia. ${ }^{45}$

One of the major sources of disputes in the IWT comes from hydroelectric power projects. ${ }^{46}$ One such dispute was the Baglihar run-of-the-river hydroelectric power projects on the Chenab River in the Indian state of Jammu and Kashmir. ${ }^{47}$ "Pakistan's approach to the Baglihar dispute was political and legal - it called for an adherence to provisions of Indus Waters Treaty and also sought to satisfy its

\footnotetext{
${ }^{36}$ Article 11.

${ }^{37}$ Article 12.

${ }^{38}$ For the text visit, http://wrmin.nic.in/writereaddata/MAHAKALI_TREATY_1996.pdf (accessed 23 May 2017).

${ }^{39}$ Article 3 of the Treaty.

${ }^{40}$ Article 9 of the Treaty.

${ }^{41}$ Article 7 of the Treaty.

${ }^{42}$ Salman and Uprety (2002) at p. 104.

${ }^{43}$ Kraska (2003) at p. 478.

${ }^{44}$ Haines (2014) at p. 640.

${ }^{45}$ Kraska (2003) at p. 481

${ }^{46}$ Dar (2011-2012) at 3.

${ }^{47}$ Pakistan objected to its design as it considered its coordinates to be too liberal than were required for the project. This was considered as a "difference" within the meaning of the IWT which led to the appointment of Raymond Lafitte as a Neutral Expert. The Expert gave it report in 2007.
} 
concerns about use of water as a strategic weapon during war. India on the other hand viewed the dispute as a difference in views on the engineering of hydroelectric plants." 48 The Baglihar Neutral Expert viewed that the principle of integration and the principle of effectiveness should guide the interpretation of the IWT so as to allow for the fulfilment of its object(s) and purpose(s). ${ }^{49}$ Later, the Kishenganga Arbitration between India and Pakistan affirmed that the minimum flow is open to reconsideration notwithstanding the principle of res judicata. ${ }^{50}$ While the Neutral Expert's findings are of considerable importance in the matters of treaty interpretation, the Kishenganga Arbitration in no small measure essentially underscored the principle of equitable and reasonable utilization in its ruling that requires India to release $100 \%$ of the flow of water if it is less than 9 cumec. $^{51}$

Besides the problematic issue of power generation projects between India and Pakistan, ${ }^{52}$ the IWT has been considered insufficient mainly because of its perceived limitations to answer questions, such as the environmental security and the capacity of the joint working mechanisms, even as the diplomatic efforts continue to prevent these issues from degenerating into disputes or vioelnce. ${ }^{53}$ Other contentious issues include the diversion of water outside the basin on the western rivers, ${ }^{54}$ adverse effects on the stream flow and saline ingress due to excessive groundwater pumping ${ }^{55}$, the challenge of climate change in the Himalayan region, ${ }^{56}$ the discharge of water into the sea by the Indus river system and increased salinity with little water flowing into the sea. ${ }^{57}$ These issues can be a cause of competing claims and conflicts. ${ }^{58}$ Despite the fact that the IWT contemplates future cooperation "experts from both sides agree that building cooperation on a treaty of division is tricky." $" 59$

Commentators have opined that Bangladesh has been dissatisfied with its share of water under the Treaty. ${ }^{60}$ It has been claimed that "the agreement was arrived at on the basis of water availability between 1949 and 1988." ${ }^{61}$ Further,

\footnotetext{
${ }^{48} \operatorname{Dar}$ (2011-2012) at 12; Sharma (1988). Further, see Malik (2005); Mehta (1988).

49 Baglihar Hydroelectric Dam, Expert Determination, Executive Summary, 12 February 2007 (Lausanne, 2007) para. 3. Salman (2008). For India's reaction, visit http://www.mea.gov.in/ pressreleases.htm?dtl/2287/Baglihar+Dam+cleared+by+neutral+expert (last accessed 6 June 2017); Gazdar (2005). Further, see generally Lauterpacht (1949).

${ }^{50}$ The Indus Waters Kishenganga Arbitration (Pakistan v India), Final Award of the Permanent Court of Arbitration, dated 20 December 2013, para. 118. The dispute arose when India started constructing a hydroelectric project on a tributary (Kishenganga/Neelum) of the Jhelum River. For a detailed background of the dispute, see Kishenganga Partial Award, para. 140 et seq.

${ }^{51}$ Ibid.

${ }^{52}$ Dar (2011-2012) at 29.

${ }^{53} \operatorname{Dar}$ (2011-2012) at 2.

${ }^{54}$ Ibid.

${ }^{55}$ Verghese (1997).

${ }^{56}$ Dar (2011-2012) at 29.

57 Ibid.

${ }^{58}$ World Commission on Water for the Twenty-First Century, Commission Report (2000). Water Secure World: Vision for Water, Life, and the Environment, 30. Cairo: World Water Council.

${ }^{59}$ Dar (2011-2012) at 29; Verghese (2005); Iyer (2005); Briscoe (2010).

${ }^{60}$ Haider (2001) at p. 425.

${ }^{61}$ Hossain (1998) at p. 142.
} 
water diversion has resulted in "the destruction of the breeding and raising grounds for a number of Gangetic species, the increase of salinity in the southwest coastal region of Bangladesh and a reduction of fish and agricultural diversity.",62 Still there is no agreement between the two parties on how "to augment the flow of the Ganges during the dry season and provide sufficient amounts of water for both parties." resolve any dispute [and] the absence of arbitration mechanisms makes this legal instrument less effective than the Mahakali Treaty" ${ }^{\prime 64}$ between India and Nepal.

While the 1996 Ganges Waters Treaty between India and Bangladesh "explicitly upholds the principle of equitable and reasonable utilization water supplies, the Treaty does not provide for any mechanism to other riparian countries of the Ganges basin for finding a long-term sustainable solution of the current crisis and for integrated management basin." 65 The no harm principle in the Ganges Treaty has been found to be "slightly different from Article 7 of the Watercourses Convention since the Treaty treats these principles on an equal footing [under which] a lower riparian state in a parched region with fully utilized rivers might claim that any use of the watercourse by an upper riparian state would be harmful to it." 66 Further, it has been noted that "the operation of the Farakka Barrage is not dealt with in the Treaty... [which] is a subject for which dispute settlement is provided implies that Bangladesh has a say in its operation since it is there that India must release the waters of the Ganges in the prescribed quantities to Bangladesh." ${ }^{67}$ And "[u]nlike the Mahakali Treaty concluded by India with Nepal, the Ganges Treaty makes no provision for judicial settlement of disputes". 68

Thus, the Ganges and Brahmaputra have water-sharing agreements but they do not involve all the states within the basin areas. Bangladesh points out that the Ganges "provides drinking water to the people, sustains agriculture, forestry and fishery, serves as the main means of transport, keeps back the saline water from the Bay of Bengal and plays a dominant part in the ecology of the region. ${ }^{, 69}$ Further, India's diversion of water has been held responsible for dry season conditions for Bangladesh. ${ }^{70}$ India points out that it has no alternative source of water to flush the Hooghly and preserve Calcutta port whereas "Bangladesh is served by alternative river systems and actually has a problem

${ }^{62}$ Gain and Giupponi (2014) at p. 2501.

${ }^{63}$ Uprety and Salman (2011) at p. 651.

${ }^{64}$ Uprety and Salman (2011) at p. 654. Further, see below the next section.

${ }^{65}$ Kasymov (2011) at p. 102. See Articles II, IX and X of the Treaty.

${ }^{66}$ Subedi (1999) at p. 961.

${ }^{67}$ Ibid.

${ }^{68}$ Ibid.

${ }^{69}$ The Law of the Non-navigational Uses of International Watercourses, Second Report (1980) 164, para. 83.

${ }^{70}$ For an examination of input-output controls, social input prices, bilateral water trade, a water market for all water users, and a fixed water allocation agreement, as possible water policies, for cross border river water sharing, see Giannias and Lekakis (1997) at p. 232. 
of surplus water, most of which flows unused down to the sea" ${ }^{71}$ It has been argued that "shifts in the discharge of the Ganges waters may occur due to both natural climatic variability and to human abstraction. India claimed that this was due to low winter and summer rainfall in northern India, while Bangladesh argued that the low flow was the result of only water diversions upstream of Farakka." 72 It is unfortunate that "Bangladesh and India were not able to form a consensus to maintain a regular flow downstream [...] because the technopolitical debate between Bangladesh and India on the impact of the Farakka Dam is based on general observation and anecdotal evidence instead of quantitative assessment of water requirements."

A more prominent dispute between India and Bangladesh concerns the sharing of the Teesta River water. ${ }^{74}$ An ad hoc agreement made in 1983, was never put into practice. ${ }^{75}$ In 2004, making a major shift from its 1983 stance, Bangladesh proposed that " $10 \%$ of the Teesta waters be kept for natural flow, $39 \%$ for India, 36\% for Bangladesh and the rest be distributed proportionately. However, India insisted that the scientific studies be first completed." ${ }^{, 76}$ It is widely believed that domestic politics in India is one of the problems in the resolution of this dispute which is also due to the lack of exclusive competence of the Indian central government to resolve it. ${ }^{77}$

The 1954 India-Nepal Kosi Project Agreement has been termed as "inappropriate" as "the barrage-building was based on knowledge of an engineering fraternity prevailing on the non-silting rivers of Europe and North America" ${ }^{78}$ And the 1959 Gandak Treaty between India and Nepal has been considered as "a bad deal for Nepal, because it had the effect of curtailing Nepal's right to Gandaki water for use inside Nepalese territory". ${ }^{79}$ Nepal still wants to further revise Article 9 of this Treaty that limits Nepal's right to use its water inside Nepal only. A dispute called, the Kalapani dispute between India and Nepal, came in the limelight in 1997 when the Mahakali Treaty came up for ratification by Nepal and could not be resolved despite several efforts. ${ }^{80}$ Thus, the experience of the India-Nepal Mahakali River Treaty of 1996 has been less than all positive as it also created a trust-deficit between the two countries due further to "the construction of a Dam at Pancheshwar, displacement of Nepali people for a purpose which will benefit India, and non-assurance of a fair price to Nepal for the electricity that the latter will export to India." 81 Thus,

\footnotetext{
${ }^{71}$ India, Ministry of External Affairs, The Farakka Barrage (New Delhi, The Statesman Press [n.d.]), "Position in International Law", cited in The Law of the Non-navigational Uses of International Watercourses, Second Report (1980) 164, para. 82.

${ }^{72}$ Gain and Giupponi (2014), at p. 2506.

${ }^{73}$ Gain and Giupponi (2014), at p. 2504. Further, see Crow et al. (1995).

${ }^{74}$ The river originates in the Indian state of Sikkim and flows through another Indian state of West Bengal before entering Bangladesh.

${ }^{75}$ Uprety and Salman (2011) at p. 655.

${ }^{76}$ Ibid.

${ }^{77}$ Further, see Ahmad (2005).

${ }^{78}$ Uprety and Salman (2011) at p. 652.

${ }^{79}$ Uprety and Salman (2011) at p. 651.

${ }^{80}$ Uprety and Salman (2011) at p. 656.

${ }^{81}$ Haider (2001) at p. 429; Gywali (1995).
} 
"[w]ater-related conflicts have a long history and will continue to be a global and regional problem." 82

And, finally, the Indian projects of the Interlinking of rivers create scope for further conflicts, ${ }^{83}$ both within the Indian states and between the countries of South Asia. ${ }^{84}$ Thus, India needs to "secure concurrence of other riparians, which may not only be difficult, but also full of tension and conflicting positions." 85 Perhaps the only common element that emerges from the functioning of these regimes is that regular institutional mechanisms have remained less than optimized, not to speak of the Indian announcement of suspension of such talks under the IWT in 2016. Clearly, a "[f]ragmented governance contradicts the advice of hydrologists, environmentalists, and engineers who argue that the optimal and sustainable approach to manage an international river is to treat it as an integral unit that respects the ecological interdependence within the ecosystem." "While the "increase in demand continues to be a catalyst for conflict," 87 "unilateral behaviour of India" 88 and the difficulty in disentangling water disputes from other bilateral problems add to and aggravate the problems shown by a fragmented legal regime of water sharing in South Asia. ${ }^{89}$

\section{Salient features of the Watercourses Convention}

State practice and juristic work prior to the coming into existence of the Convention on the Law of the Non-Navigational Uses of International Watercourses, 1997 (the Watercourses Convention), show at least four principles of international river water-sharing. Of these, the Absolute Territorial Sovereignty principle allows a state to use the waters of a river in its territorial limits without any regard for harm it causes to other riparian states. Opposed to this is the Absolute Territorial Integrity Principle which allows the lower riparian state to require the upper riparian state to allow for the natural flow of an international river. The Third is the Equitable and Reasonable Utilization principle which combines the earlier two principles and is the most acceptable principle today. ${ }^{90}$ And, finally, there is the principle of Community of Co-Riparian States. This principle requires substitution of individual rights of riparian states with that of their collective right ignoring the territorial aspects of individual riparian states. ${ }^{91}$

\footnotetext{
${ }^{82}$ Zhang (2016) at p. 163.

${ }^{83}$ For a background note, visit the official website of the Indian Ministry of Water Resources at http://wrmin.nic.in/forms/list.aspx?lid=1279.

${ }^{84}$ Further, see Gourdji (2005); Upreti (2005).

${ }^{85}$ Uprety and Salman (2011) at p. 656; Sultana (2004).

${ }^{86}$ Zawahri and McLaughlin Mitchell (2011) at p. 836; Mirza (2004).

${ }^{87}$ Uprety and Salman (2011) at p. 643.

${ }^{88}$ Adhikari (2014) at pp. 45, 56.

${ }^{89}$ Shah and Giordano (2013) at p. 30. Further, see Frederick (1996).

${ }^{90}$ Further, for instance, see above, Section III, discussion on the legal regime between India and Bangladesh.Lipper (1967).

${ }^{91}$ Further, see generally Earle et al. (2010); Caponera (2007); Giordano and Wolf (2002); Wouters (2011); McCaffrey (2007).
} 
The Convention is a product of the ILC, which started working on it as early as 1971. On 21 May 1997, the United Nations General Assembly adopted the Watercourses Convention and invited countries to become parties to it. ${ }^{92}$ Of the SAARC member countries, Bangladesh, Bhutan and Nepal were its sponsors. Maldives was in its favour. India and Pakistan abstained. Afghanistan and Sri Lanka were absent. It came into force on 17 August 2014, with 34 parties. ${ }^{93}$ But insofar as it reflects customary international law, it is binding on non-parties. ${ }^{94}$

The Convention defines a watercourse as a single unit of surface and underground waters that includes the main river, its tributaries and distributaries, and any connected lakes, wetlands, and aquifers. The principle of equitable and reasonable utilization contained in the Convention is widely viewed as a codification of customary international law. ${ }^{95}$ A non-exhaustive list of factors and circumstances which states are required to consider for the purposes of equitable and reasonable utilization and participation is given in Article $6 .{ }^{96}$ Under the obligation not to cause significant harm, ${ }^{97}$ a riparian state, which believes that it has sustained significant harm due to the activities of a co-riparian state, may take up the matter with the co-riparian state which is required to reach an equitable and reasonable solution. This principle is also widely viewed as a codification of customary international law. Another principle contained in the Convention is the principle of prior notification of planned measures by which a state, in which a planned activity may have a significant adverse effect upon another state or states sharing an international watercourse, is required to provide timely notification of the plans to the other states. Consultations and negotiations are required to be undertaken with a view to reaching an equitable resolution if the notified states believe that the planned measures would be inconsistent with the Convention. ${ }^{98}$

\footnotetext{
${ }^{92}$ UN Doc. A/51/PV.99.

${ }^{93}$ Further, see Salman (2015).

${ }^{94}$ Further, see McCaffrey and Sinjela (1998); Helal (2007); Tanzi and Arcari (2001). Further, see generally, Fitzmaurice, Malgosia (2002).

${ }^{95}$ Article 5. This principle is also contained in the Law of Transboundary Aquifers, UN GA Res. 63/124, dated 15 January 2009.See also Gabčíkovo-Nagymaros Project (Hungary/ Slovakia), ICJ Reports 1997, 7, para. 85.

96 Article 5 of the Law of Transboundary Aquifers: Factors relevant to equitable and reasonable utilization: 1. Utilization of a transboundary aquifer or aquifer system in an equitable and reasonable manner within the meaning of article 4 requires taking into account all relevant factors, including: (a) The population dependent on the aquifer or aquifer system in each aquifer State; (b) The social, economic and other needs, present and future, of the aquifer States concerned; (c) The natural characteristics of the aquifer or aquifer system; (d) The contribution to the formation and recharge of the aquifer or aquifer system; (e) The existing and potential utilization of the aquifer or aquifer system; (f) The actual and potential effects of the utilization of the aquifer or aquifer system in one aquifer State on other aquifer States concerned; ( $\mathrm{g}$ ) The availability of alternatives to a particular existing and planned utilization of the aquifer or aquifer system; (h) The development, protection and conservation of the aquifer or aquifer system and the costs of measures to be taken to that effect; (i) The role of the aquifer or aquifer system in the related ecosystem.

${ }^{97}$ Article 7. This principle is also contained in the Law of Transboundary Aquifers, UN GA Res. 63/124, dated 15 January 2009.

${ }^{98}$ Rieu-Clarke (2010).
} 
Commentators believe that the Convention subordinates the obligation not to cause significant harm to the principle of equitable and reasonable utilization. ${ }^{99}$ The reasons for the reluctance of states to ratify or accede to the Convention "considerable ambiguity as to which of the two principles prevails." 100 However, one of the basic obligations under the Convention is the obligation to cooperate. ${ }^{101}$ The Convention does not necessarily require abrogation of the existing arrangements but allows future arrangements in accordance with the equitable and reasonable utilization principle. ${ }^{102}$ The Convention's approach underscores the considerations of genuine human needs and protection against pollution. ${ }^{103}$ Its implementation mechanism, like the Helsinki Rules, ${ }^{104}$ is flexible and not rigid to allow for a balancing of interests.

\section{Conclusions}

Uprety and Salman, ${ }^{105}$ while advocating built-in flexibility, adaptive allocation, redefining availability, choosing an adequate method in transboundary water-sharing and a vision for cooperative development, underscore that the Watercourses Convention is "the only international "framework law" applicable to transboundary waters" "106 and discount "a formal conclusion as to why the South Asian countries are uncomfortable with the Convention."107 This is not to ignore the differing national positions on the Convention. ${ }^{108}$ However, even when South Asian countries have opposed the Convention they have used its principles or reasoning for defending their positons. For instance, according to India, the "[a]ssertion of a right to "natural flow" amounts to exercising a veto on the rights of upper riparians to reasonable and equitable shares of the waters of common rivers. ${ }^{109}$ As noted above, the 2007 Decision by the Neutral Expert on

\footnotetext{
${ }^{99}$ See for instance Bourne (1997).

${ }^{100}$ Salman (2007) at p. 634.

${ }^{101}$ Article 8 .

${ }^{102}$ See generally, Rieu-Clarke et al. (2012).

${ }^{103}$ Further, see generally McCaffrey (2008).

104 http://www.internationalwaterlaw.org/documents/intldocs/Helsinki_Rules_with_comments.pdf (last accessed 29 May 2017); Salman (2007) at p. 631.

${ }^{105}$ Uprety and Salman (2011) at p. 657.

${ }^{106}$ Uprety and Salman (2011) at pp. 659-60; Rojas and Iza (2007); Iyer (2007).

${ }^{107}$ Uprety (2014). Further, see generally Iza and Stein (eds.) (2009).

${ }^{108}$ For example, Pakistan is against "groundwater" being part of the watercourse definition of a "watercourse", also because it is inequitable to include aquifers that are located entirely within the territory of one country. India considers that the Convention in Article 3 contradicts its domestic law whereby water is constitutionally a state rather than a Union matter. It also believes that the term "sustainable" is ill defined in Articles 3 and 5 in the context of sustainable utilization. Moreover, all SAARC countries give different interpretation to the word "significant" in the context of "no significant harm" in Article 7. And all of them do not accept Article 32 on equality of access to transboundary remedies which is taken as presupposing regional integration. Bangladesh prefers the concept of international river basin to that of international watercourse. Further, see the Replies of the Governments to the Commission's Questionnaire, General comments of Bangladesh, Yearbook of ILC 1982, vol. II(i), A/CN.4/352 and Add.1, at 193.

${ }^{109}$ India, Ministry of External Affairs, The Farakka Barrage (New Delhi, The Statesman Press
} 
the Baglihar Issue and the 2013 Kishenganga Arbitration are not without normative elements that serve to essentially corroborate the parties' substantive consent to the principles of water sharing contained in the Watercourses Convention. Their undertaking to abide by the terms of the Expert's findings and the Award is not without significantly contributing to the state practice to be appropriately available in due course as applicable law in the prevention and resolution of water sharing issues. ${ }^{110}$ There is no reason why the countries of South Asia cannot share water "in an ecologically sustainable manner that respects the interdependence between different users"111 and for the whole range of issues involved become parties to the Watercourses Convention with any appropriate reservations and/or declarations. ${ }^{112}$ For one, the dispute settlement provision of the Watercourses Convention does not require derogation from the existing dispute settlement provisions contained in the bilateral instruments of the South Asian countries.India, Pakistan and Bangladesh have settled their disputes by arbitration. ${ }^{113}$ And India and Pakistan are currently litigating before the International Court of Justice. ${ }^{114}$ In other words, the Watercourses Convention is not merely codificatory of the customary international law ${ }^{115}$ but it is also evidentiary of certain relevant principles of international law for treaty interpretation. ${ }^{116}$

International law is no longer devoid of an obligation to cooperate. ${ }^{117}$ Water as a shared South Asian natural resource is sufficient to require an

[n.d.]), "Position in International Law", cited in The Law of the Non-navigational Uses of International Watercourses, Second Report (1980) 164, para 82. Further, see Lipper (1967).

${ }^{110}$ Further, see Villiger (1997) at p. 17; Mendelson (1998); Kelley (2000); ILC, Report of the International Law Commission on the work of its 68th session (2 May-10 June and 4 July-12 August 2016) UN Doc. A/71/10.

${ }^{111}$ For instance, the water can be stored in upstream Nepal for release during the dry season to increase the river's flow and dilute its pollution. Zawahri and McLaughlin Mitchell (2011) at p. 836; World Bank (2010); Fitzmaurice (1998).

${ }^{112}$ Further, see Uprety and Salman (2011);Magsig (2009); UN-Water (2008) at p. 7;Sadoff and D Grey (2005); Bhaduri and Barbier (2003) at p. 47; Uprety (2012); Rahaman (2009); Wouters et al (2005); Hooper and Lloyd (2011); Price (2013) at p. 36; Iyer (2007).

${ }^{113}$ See, for instance, Pratap (2015). Further, see Jägerskog and Zeitoun (2009).

${ }^{114}$ Jadhav Case (2017). Kamruzzaman et al. (2012); Dore et al. (eds.) (2010); Tanzi (2010).

115 As evidenced by the IWT, the India-Nepal Kosi Project Treaty (1954), the India-Nepal Gandak Treaty (1959), the Ganges and Mahakali Treaties.

${ }^{116}$ Including customary international law, as testified by the practice of the dispute settlement mechanisms agreed between the South Asian countries, such as the Baglihar Neutral Expert (2007) and the Kishenganga Arbitration (2013).

${ }^{117}$ North Sea Continental Shelf Cases, ICJ Reports 1969, 47, para. 85; UN Friendly Relations Declaration, GA Res. 2625 of 24 October 1970 casts on states a duty to cooperate; Article 3 of the 1974 Charter of Economic Rights and Duties of States: "In the exploitation of natural resources shared by two or more countries each State must cooperate on the basis of a system of information and prior consultations in order to achieve optimum use of such resources without causing damage to the legitimate interest of others", UN GA Res. 3281 (XXIX) of 12 December 1974; United States - Import Prohibition of Certain Shrimp and Shrimp Products: Recourse to Article 21.5 of the DSU by Malaysia, WTO Doc. WT/DS58/AB/RW, AB-2001-4 (22 October 2001) para. 134; The work of the ILC affirms a broad principle that states, even when undertaking acts that international law did not prohibit, had a duty to consider the interests of other states that might be affected, Yearbook of the International Law Commission 
institutional response by the South Asian country members of SAARC. ${ }^{118}$ SAARC was founded no earlier than 1985 and after formulation of their above objections to certain formulation of the Watercourses Convention. Cooperation as an international obligation is sufficient to require cooperation of the SAARC countries, such as on the lines of SAARC Regional Centres, for providing a necessary institutional support for the implementation of equity, reasonableness, flexibility, and adaptation in the South Asian water sharing. ${ }^{119}$ Ready availability of an institutional mechanism is necessary as a means of dispute avoidance in the context of the obligation of states to settle their disputes by peaceful means and as a corollary to the jus cogens nature of the prohibition of the threat or use of force in international relations.

\section{References}

Abbas, B. M. (1984). The Ganges Water Dispute. Dhaka: University Press.

Adhikari, K. N. (2014). 'Conflict and Cooperation on South Asian Water Resources.' IPRI Journal 14: 45-62.

Ahmad, E. (2005). 'Bangladesh Water Issues.' South Asian Journal April-June: 55-67.

AyubQutub, S. et al. (2003). Water Sharing Conflicts within Countries, and Possible Solutions. Hawaii: Global Environment and Energy in the $21^{\text {st }}$ Century.

Barber, F. J. (1981). Rivers in International Law. London: London Institute of World Affairs [R K Baxter Trans.].

Benevisti, E. (2002). Sharing Transboundary Resources: International Law and Optimal Resource Use. Cambridge: Cambridge University Press.

Bhaduri, A. and E. Barbier (2003). 'Water Transfer and International River Basin Cooperative Management: The Case of the Ganges.' University of Wyoming Paper.

Biswas, A. (1992). 'Indus Waters Treaty - the negotiating process.' Water International 17: 201-209.

Biswas, A. (2011). 'Cooperation or conflict in transboundary water management: Case study of South Asia.' Hydrological Sciences Journal 56: 662-670.

Boisson de Chazournes, L. (2009). Freshwater and International Law: The Interplay between Universal, Regional and Basin Perspectives (Paris: UNESCO).

Bourne, C.B. (1997).'The Primacy of the Principle of Equitable Utilization in the 1997 Watercourse Convention.' Canadian Yearbook of International Law 35: 215-232.

Briscoe, J. (2010). 'Troubled Waters: Can a Bridge Be Built over the Indus.' Economic and Political Weekly 50: 28-32.

Caponera, D.A. (2007). Principles of Water Law and Administration: National and International. London: Taylor and Francis.

Chellaney, B. (2011). Water: Asia's New Battleground. Washington D.C.: Georgetown University Press.

Crow, B. et al. (1995). Sharing the Ganges: The Politics and Technology of River Development. New Delhi: Sage Publications.

(1980), vol. II (2) 159. This principle is also contained in Article 7 of the Law of Transboundary Acquifers, UN GA Res. 63/124, dated 15 January 2009; Wouters (2015).

${ }^{118}$ Further, see Vinogradov et al. (2003); Moynihan and Magsig (2014).

${ }^{119}$ On the lines of a number of SAARC Regional Centres already established in several areas. 
Dar, Z.A. (2011-2012). 'Power Projects in Jammu and Kashmir: Controversy, Law and Justice.' LIDS Working papers, Harvard Law \& International Development Society.

Dore, J. et al. (eds.) (2010). Negotiate - Reaching Agreements over Water. Gland: IUCN.

Earle, A. et al. (2010). Transboundary Water Management: Principles and Practice. London: Earthscan.

Fitzmaurice, M. (1998). 'Water Management in the $21^{\text {st }}$ Century.' In Anghie, A. and G Sturgess (eds.). Legal Visions of the $21^{\text {st }}$ Century: Essays in Honour of Judge Christopher Weeramantry, 425-63. The Hague: Kluwer.

Fitzmaurice, M. (2002).'Third Parties and the Law of Treaties.' Max Planck Encyclopedia of Public International Law, http://www.mpil.de/files/pdf1/mpunyb_fitzmauri ce_6.pdf (accessed 3 June 2017).

Frederick, K. D. (1996). 'Water as a source of International Conflict.' Resources 123: 9-12.

Gain, A.K. and C. Giupponi (2014). 'Impact of the Farakka Dam on Thresholds of the Hydrologic Flow Regime in the Lower Ganges River Basin (Bangladesh).' Water 6: $2501-2518,2501$.

Gazdar, H. (2005). 'Baglihar and Politics of Water: A Historical Perspective from Pakistan.' Economic and Political Weekly 40: 813-17.

Giannias, D.A. and J.N. Lekakis (1997).'Policy analysis for an amicable, efficient and sustainable inter-country fresh water resource allocation.'Ecological Economics 21: 231-241.

Giordano, M.A. and A.T. Wolf. (2002).'The world's freshwater agreements: historical developments and future opportunities.' In Atlas of International Freshwater Agreements, 1-8. Nairobi: UNEP.

Gleick, Peter H. (1993). 'Water and Conflict: Fresh Water Resources and International Security.' International Security 18: 79-112.

Gourdji, S. et al. (2005). Indian Inter-linking of Rivers: A Preliminart Assessment, Project Report, University of Michigan, 4-162 (2005), http://rivers.snre.umich.edu/gan ga/India/RiverLinkingFinal.pdf(accessed 29 May 2017).

Gulhati, Niranjan D. (1973). Indus Waters Treaty: An Exercise in International Mediation. Bombay: Allied Publishers.

Gyawali, D. (2002). 'Water beyond the State: Resolving Conflicts with Institutional Pluralism.' In P. Sahadevan (ed.). Conflicts and Peacemaking in South Asia, 396416. New Delhi: Lancer Publications;

Gyawali, D. (1995). 'Himalayan Water: Between Euphoric Dreams and Ground Realities.' In K.Bahadur \& M. P. Lama, eds., New Perspectives on Indo-Nepal Relations, 247-259. New Delhi: HarAnand.

Haines, D. (2014). 'Disputed Rivers: Sovereignty, Territory and State-Making in South Asia.' Geopolitics 19: 632-655.

Haider, Z. (2001). 'Crises of Regional Cooperation in South Asia.'Security Dialogue 32: 423-437.

Helal, M. S. (2007). 'Sharing Blue Gold: the 1997 UN Convention on the Law of the Non-Navigational Uses of International Watercourses Ten Years on.' Colorado Journal of International Environmental Law and Policy 18: 337-378.

Hooper, B.P. and G.J. Lloyd (2011).Report on Integrated Water Resource Management in Transboundary Basins. Nairobi: UNEP.

Hossain, I. (1998). 'Bangladesh-India Relations: The Ganges Water-Sharing Treaty and Beyond.'Asian Affairs 25: 131-150. 
Islam, R. (1984). 'The Effects of Farakka Barrage on Bangladesh and International Law.'Bangladesh Institute of International and Strategic Studies Journal 5: 249273.

Iyer, R. (1999). 'Conflict-resolution: Three river treaties.' Economic and Political Weekly 34: $1509-18$.

Iyer, R. (2005). 'Indus Treaty: A Different View', 40 Economic and Political Weekly 40: $3140-44$.

Iyer, R. (2007). Towards water wisdom: limits, justice, harmony. New Delhi: Sage Publications.

Iza, A. and R. Stein (eds.) (2009).RULE - Reforming Water Governance. Gland: IUCN.

Jägerskog, A. and M. Zeitoun (2009).Getting Transboundary Water Right: Theory and Practice for Effective Cooperation, SIWI Report No. 25. Stockholm: International Water Institute.

Kamruzzaman, M. et al. (2012). "A model for water sharing in the Ganges River Basin." Water Environment Journal 26: 308-318.

Kasymov, S. (2011). 'Water Resources Disputes: "Conflict and Cooperation in Drainage Basins.' International Journal of World Peace 28: 81-110.

Kelley, J.P. (2000). 'The Twilight of Customary International Law.'Virginia Journal of International Law 40: 449-544.

Kraska, J. (2003). 'Sustainable development is security: The role of transboundary river agreements as a confidence building measure in South Asia.', Yale Journal of International Law 28: 465-504.

Kumar, V. and S.K. Jain.(2011). 'Trend in rainfall amount and number of rainy days in river basins of India (1951-2004).' Hydrology Research 42: 290-306.

Lauterpacht, H. (1949). 'Restrictive Interpretation and the Principle of Effectiveness in the Interpretation of Treaties.' British Yearbook of International Law 26: 48-85.

Lipper, J. (1967). 'Equitable Utilisation.' In A. H. Garretson et al. (eds.), The Law of the International Drainage Basins, 16-26. New York: Oceana.

Magsig, B.O. (2009). 'Introducing an analytical framework for water security: a platform for the refinement of international law.' Journal of Water Law 20: 61-69.

Malik, B.A. (2005). Indus Waters Treaty In Retrospect. Lahore: Brite Book.

McCaffrey, S.C. (2007). The Law of International Watercourses. London: Oxford.

McCaffrey, S.C. (2008). 'The 1997 UN Watercourses Convention: retrospect and prospect.' Global Business and Development Law Journal 21: 165-174.

McCaffrey, S.C. and M. Sinjela (1998).'The 1997 United Nations Convention on International Watercourses.'American Journal of International Law 92: 97-107.

Mehta, J.S. (1988). 'The Indus Water Treaty: A Case Study in the Resolution of an International River Basin Conflict.' Natural Resources Forum 12: 69-77.

Mendelson, M.H. (1998). 'The Formation of Customary International Law.'Recueil des Cours 272: 155-410.

Michel, A.A. (1967). The Indus Rivers: A Study of the Effects of Partition. New Haven: Yale University Press.

Miner, M. et al. (2009). 'Water Sharing Between India and Pakistan: A Critical Evaluation of the Indus Waters Treaty.' Water International 34: 204-216.

Mirza, M.M.Q. (2004). The Ganges Water Diversion: Environmental Effects and Implications. Dordrecht: Springer.

Moynihan, R. and B.O. Magsig (2014). 'The Rising Role of Regional Approaches in International Water Law: Lessons from the UNECE Water Regime and Himalayan Asia for Strengthening Transboundary WaterCooperation.' Review of European, Comparative and International Environmental Law 23: 43-58.

Pratap, R. (2015), 'India-Bangladesh Maritime Boundary Award.' LAWASIA Journal 
$1-18$.

Price, G. (2013). 'Floating Ideas on Water Sharing.'The World Today 69: 34-36.

Priscoli, J. D. and A.T. Wolf (2009).Managing and Transforming Water Conflicts. Cambridge: Cambridge University Press.

Qureshi, A.S. (2011). 'Water Management in the Indus Basin in Pakistan: Challenges and Opportunities.' Mountain Research and Development 31: 252-260.

Rahaman, M.M. (2006). 'The Ganges Water Conflict: A Comparative Analysis of 1977 Agreement and 1996 Treaty.' Journal of International \& Peace Studies 1: 195-208;

Rahaman, M.M. (2009). 'Integrated Ganges Basin management: Conflicts and hope for regional development.' Water Policy 11: 168-190.

Rieu-Clarke, A. (2010). 'The role of treaties in building international watercourses regimes: a legal perspective on existing knowledge.' Water Policy 12: 822-831.

Rieu-Clarke, A. et al. (2012). UN Watercourses Convention: User's Guide. Dundee: CWLPS.

Rojas, G.A. and A. Iza (2007).Governance of Shared Waters.Legal and Institutional Issues. Gland: IUCN.

Sadoff, C.W. and D. Grey (2005). 'Cooperation on international rivers: a continuum for securing and sharing benefits.' Water International 30: 420-427.

Sadoff, C. et al. (eds.) (2008). Share: Managing Water across Boundaries. Gland: IUCN.

Salman, S.M.A. (2007), 'The Helsinki Rules, the UN Watercourses Convention and the Berlin Rules: Perspectives on International Water Law.' Water Resources Development 23: 625-640.

Salman, S.M.A. (2008). 'The Baglihar difference and its resolution process - a triumph for the Indus Waters Treaty.'Water Policy 10: 105-117.

Salman, S.M.A. (2015). 'Entry into force of the UN Watercourses Convention: why should it matter?' International Journal of Water Resources Development 31: 4-16.

Salman, S.M.A. and K. Uprety (2002).Conflict and Cooperation on South Asia's International Rivers: A Legal Perspective. Washington, D.C.: World Bank.

Shah, T. and M. Giordano. (2013). 'Himalayan Water Security: A South Asian Perspective.' Asia Policy 16: 26-31.

Sharma, K.S. (1988). 'India's Experience in Developing the Indus River Basin Programme.' In United Nations Department of Technical Cooperation, Natural Resources Water Series No. 20, River and Lake Basin Development, Proceedings of the United Nations Meeting at Addis Ababa, Ethiopia 10-15 October, 194202.

Subedi, S.P. (1999). 'Hydro-Diplomacy in South Asia: The Conclusion of the Mahakali and Ganges River Treaties.' American Journal of International Law 93: 953-962.

Sultana, F. (2004). 'Engendering a catastrophe: A gendered analysis of India's river linking project.'In M.F. Ahmed and Q.K. Ahmad (eds.) (2004).Regional Cooperation on Transboundary Rivers: Impact of the Indian River-linking Project, 288-305. Dhaka: BAPA Press.

Swain, A. (2004). Managing Water Conflict: Asia, Africa and the Middle East. London: Routledge.

Tanzi, A. (2010). 'Reducing the gap between international water law and human rights law: the UNECE Protocol on Water and Health.' International Community Law Review 12: 267-285.

Tanzi, A. and M. Arcari (2001).The United Nations Convention on the Law of International Watercourse. The Hague: Kluwer.

Tarlock, A.D. (2008). 'Water security, fear mitigation and international water law.' Hamline Law Review 31: 703-728. 
Türk, H. (2012). 'Water in the Contemporary World.' In: Holger P. Hestermeyer et al (eds.). Coexistence, Cooperation and Solidarity: Liber AmicorumRüdigerWolfrum 1037-1064. The Hague: MartinusNijhoff.

Upreti, T. (2005). International Watercourses Law and Its Application in South Asia. Kathmandu: Pairavi, Chapter V.

Uprety, K. (2012). Transboundary water governance: Lessons for South Asia, 3 September 2012, http://www.globalwaterforum.org/2012/09/03/transboundary-wa ter-governance-lessons-for-south-asia.

Uprety, K. (2014). 'A South Asian Perspective on the UN Watercourses Convention.' http://www.internationalwaterlaw.org/blog/2014/07/14/dr-kishor-uprety-a-southasian-perspective-on-the-un-watercourses-convention/(accessed 14 May 2017).

Uprety, K. and S.M.A. Salman (2011). 'Legal Aspects of Sharing and Management of Transboundary Waters in South Asia.', Hydrological Sciences Journal 56: 641661.

Verghese, B.G. (1997). 'Water Conflicts in South Asia.' Studies in Conflict and Terrorism 20: $184-194$.

Verghese, B.G. (2005). 'It's time for Indus II: a new treaty will help the peace process too.' The Tribune, 26 May, http://www.tribuneindia.com/2005/20050526/edit. htm\#4 (accessed 13 April 2017);

Villiger, M.E. (1997). Customary International Law and Treaties: A Manual on the Theory and Practices of the Interrelation of Sources. The Hague: Kluwer, 17.

Vinogradov, S. et al. (2003).Transforming Potential Conflict into Cooperation Potential: the Role of International Water Law. Paris: UNESCO.

Wirsingh, R. (2011), 'Perilous Waters: The Changing Crises of River Rivalry in South Asia.' Whitehead Journal of Diplomacy and International Relations 12: 39-62, 39.

Wouters, P. (2011). 'The international law of watercourses: new dimensions.' Collected Courses of the Xiamen Academy of International Law. 3: 349-541.

Wouters, P. (2015). 'Addressing water security challenges - the international law 'duty to cooperate' as a limit on absolute state sovereignty.'In T. Tvedt et al. (eds.) (2015). History of Water Series III: Sovereignty and the Development of International Water Law, 334-356. London: I.B Tauris \& Co.

Wouters, P. et al. (2005). Sharing Transboundary Waters - an Integrated Assessment of Equitable Entitlement: the Legal Assessment Model. Paris: UNESCO.

Wouters, P. and A. Rieu-Clarke (2004). 'Good water governance: A call for renewed focus and action.' Journal of Water Law 15: 89-92.

Zacklin, R. and L. Caflish (eds.) (1981). The Legal Regime of International Rivers and Lakes. The Hague: Martinus Nijhoff.

Zawahri, N.A. and S. McLaughlin Mitchell (2011). 'Fragmented Governance of International Rivers: Negotiating Bilateral versus Multilateral Treaties.' International Studies Quarterly 55: 835-858.

Zhang, H. (2016). 'Sino-Indian Water Disputes: The Coming Water Wars?', WIREs Waters 3: 155-166.

\section{Instruments}

1996 Mahakali Treaty between India and Nepal, http://wrmin.nic.in/writereaddata/ MAHAKALI_TREATY_1996.pdf (accessed 23 May 2017).

Law of Transboundary Acquifers, UN GA Res. 63/124, dated 15 January 2009. 
The 1954 India-Nepal Agreement (revised in 1996) on the Kosi River Project, https:// www.internationalrivers.org/sites/default/files/attached-files/treaties_between_ne pal-india.pdf (accessed 05 June 2017).

The 1959 Gandak River Treaty between India and Nepal (amended 1964), https:// www.internationalrivers.org/sites/default/files/attached-files/treaties_between_ne pal-india.pdf (accessed 05 June 2017).

The Indus Waters Treaty, 1960, http://siteresources.worldbank.org/INTSOUTHASIA /Resources/223497-1105737253588/IndusWatersTreaty1960.pdf (accessed 13 April 2017).

Treaty between the Government of the People's Republic of Bangladesh and the Government of the Republic of India on the Sharing of the Ganga/Ganges Waters at Farakka, 1996, http://www.jrcb.gov.bd/attachment/Gganges_Water_Sharing_ treaty,1996.pdf (accessed 29 April 2017).

UNGA Res. 2625 of 24 October 1970, Friendly Relations Declaration.

UNGA Res. 3281 (XXIX) of 12 December 1974.

\section{Cases}

Baglihar Hydroelectric Dam, Expert Determination, Executive Summary, 12 February 2007 (Lausanne, 2007).

Case Concerning Pulp Mills on the River Uruguay (Argentina v. Uruguay), International Court of Justice, http://www.icj-cij.org/docket/files/135/15877.pdf.

Gabčíkovo-Nagymaros Project (Hungary/Slovakia), ICJ Reports 1997, 7.

ILC, Report of the International Law Commission on the work of its 68th session (2 May-10 June and 4 July-12 August 2016) UN Doc.A/71/10.

North Sea Continental Shelf Cases, ICJ Reports 1969, 47.

\section{Reports}

The Indus Waters Kishenganga Arbitration (Pakistan v. India), Final Award of the Permanent Court of Arbitration, dated 20 December 2013.

The Indus Waters Kishenganga Arbitration (Pakistan v. India), Partial Award of the Permanent Court of Arbitration, dated 18 February 2013.

The Law of the Non-navigational Uses of International Watercourses, First Report on the law of non-navigational uses of international watercourses by Mr Stephen M Schewebel, Special Rapporteur, A/CN.4/320 and Corr.1, Yearbook of the International Law Commission 1979, vol. II (1).

The Law of the Non-navigational Uses of International Watercourses, Second Report on the law of non-navigational uses of international watercourses by Mr Stephen M Schewebel, Special Rapporteur, A/CN.4/332 and Corr.1 and Addl. 1, Yearbook of the International Law Commission 1980, vol. II (1). [ILC Second Report].

The Law of the Non-navigational Uses of International Watercourses, Third Report on the law of non-navigational uses of international watercourses by Mr Stephen M Schewebel, Special Rapporteur, A/CN.4/348 and Corr.1, Yearbook of the International Law Commission 1982, vol. II (1).

UN-Water. (2008). Transboundary Waters: Sharing Benefits, Sharing Responsibilities Zaragoza: United Nations. 
United States - Import Prohibition of Certain Shrimp and Shrimp Products: Recourse to Article 21.5 of the DSU by Malaysia, WTO Doc. WT/DS58/AB/RW, AB-2001-4 (22 October 2001).

World Bank (2010). Sustaining Water for All in a Changing Climate, World Bank Group Implementation Progress Report. Washington D. C.: World Bank.

World Commission on Water for the Twenty-First Century, Commission Report (2000). Water Secure World: Vision for Water, Life, and the Environment, 30. Cairo: World Water Council. 
